\title{
SOUTH AFRICAN ARMY RANKS AND INSIGNIA
}

\section{By W/02 Arthur Radburn*}

Like many other aspects of South Africa's military tradition, our rank system is derived from that of the British Army. It has, however, been modified and developed over the years to suit our own particular requirements, and has become a distinctive system in its own right. This article is a brief survey of developments since the army was organised in 1912.

\section{ORIGINAL RANK STRUCTURE}

At its inception the army was considerably smaller than it is now, and it therefore required only a limited hierarchy of ranks.

Regulations promulgated in 1912 provided for only the following grades:
Officers
Brigadier-general, colonel, lieutenant-colonel, major, cap- tain, lieutenant;
Other Ranks : Warrant officer, staff sergeant, sergeant, corporal, lance-cor- poral, private. ${ }^{1}$

We apparently had no need for second lieutenants at that time, and they were introduced only at the end of World War I.

Although the regulations did not specify rank insignia, it is clear from contemporary photographs that British Army badges were worn, with the important distinction that, whereas British officers wore their badges on their cuffs at that time, South Africans wore their badges on their shoulder straps. Warrant officers' badges were worn on the forearm, and non-commissioned officers' badges were worn on the upper arm. The brigadier-general wore a crossed sword and baton, the colonel a crown and two stars, the lieutenant-colonel a crown and one star, the major a crown, and the captain and the lieutenant respectively three and two stars. The crown was the "Tudor" or "king's" pattern and the star, popularly called a "pip", was based on the Order of the Bath.

Warrant officers also wore a crown, those holding senior positions having a laurel wreath around the badge. Staff sergeants had a crown over three chevrons, sergeants three chevrons, corporals two and lance-corporals one. ${ }^{2}$

\section{COMMANDO RANKS}

It appears that officers in the Defence Rifle Asociations (i.e. commandos) used the traditional rank titles of commandant, field cornet and assistant field cornet, commandant apparently being equivalent to major. When the commandos were organised into mounted brigades for the 1914-15 German South West Africa campaign majors were designated junior commandants and the title senior commandant (ranking as lieutenant-colonel) was introduced for unit commanders. Lieutenant-colonels commanding wings (i.e. half-brigades) were designated colonels-commandant. ${ }^{3}$ This arrangement was done away with at the end of $1920 .^{4}$

\section{EXPANSION OF THE RANK STRUCTURE}

The rank of second lieutenant (wearing one star) was introduced in $1918 .{ }^{5}$ It was by no means a new rank though, but it had not been used in South Africa for some time. In 1921 the warrant officers were divided into two classes, following the example set by the British Army six years earlier. ${ }^{6}$ Warrant officers second class kept the crown as their rank badge while the first class adopted the South African coat of arms; as before senior appointments were indicated by wreathing the badges in laurel leaves so that there were four badges for the two ranks. ${ }^{7}$ Interestingly enough, although new artistic renditions of the coat of arms were adopted for official us in 1930 and 1932, the defence force has stuck to the version adopted in 1921.

Four more general ranks were authorised to coincide with the reorganisation of the Permanent Force in 1923, although it was several years before they were all filled: field marshall (a crown over crossed batons in a wreath), general (a crown, a star and crossed sword and baton), lieutenant-general (a crown and crossed sword and baton), and major-general (a star and crossed sword and baton). ${ }^{8}$ 
By then the British Army had abandoned the rank of brigadier-general in favour of a field rank, initially designated colonel-commandant and then brigadier. But South Africa retained the brigadier-generals, and when the rank of colonel-commandant - not to be confused with the World War I commando title - was finally introduced in 1937, it was as an additional grade, sandwiched in between colonel and brigadiergeneral and wearing a crown and three stars. ${ }^{9}$ Only in 1940 did we fall back in line with the British by abolishing brigadier-generals and renaming the colonel-commandant a brigadier. ${ }^{10}$ Presumably this was bacause our two armies were serving together and uniformity of rank structure was desirable.

\section{WOMEN'S AUXILIARY ARMY SERVICE RANKS}

When women were admitted to the army in 1940 it was decided to give their officers bands of red cloth across their shoulder straps to indicate their ranks: one, two or three $12 \mathrm{~mm}$ wide bands for second lieutenants, lieutenants and captains respectively, a $25 \mathrm{~mm}$ wide band for majors, and one of each width for lieutenant-colonels. This idea was abandoned in December 1941 in favour of the ordinary rank badges as worn by men. ${ }^{11}$

\section{NEW TITLES AND BADGES}

Our first postwar Minister of Defence, Frans Erasmus, made many changes to the rank system as part of his general policy of giving the defences less of a British and more of a South African flavour. The old Boer commando tradition appears to have provided much of his inspiration.

Non-commissioned officers' chevrons were changed from the British pattern to a deep Vshape, reminiscent of German insignia, in about $1949,{ }^{12}$ and in 1951 the British rank star was replaced by a five-pointed star, the points of which were said to represent the four provinces plus South West Africa. ${ }^{13}$ The title lieutenant-colonel was changed to commandant in $1950 .{ }^{14}$

In 1956 the rank of general was renamed commandant-general, with three stars and the crossed sword and baton as insignia; the new title was also used to denote the appointment previously known as Chief of the General Staff and now called Chief of the SADF. ${ }^{15}$ Six months later, in 1957, the crown was superseded by the castle rank badge. Brigadiers, colonels, commandants, majors and staff sergeants simply substituted the new badge for the old, but generals and warrant officers adopted new arrangements of insignia: crossed sword and baton with one (major-general), two (lieutenant-general) or three (commandant-general) castles for the generals, while the wreathed coat of arms became the badge of all warrant officers first class in order to free the unwreathed arms for the warrant officers second class. ${ }^{16}$

When Mr Erasmus relinquished the Defence portfolio as the end of 1959 he left behind him several more new rank titles: general (instead of lieutenant-general), combat general (instead of major-general), field cornet (instead of captain), sub-lieutenant (instead of second lieutenant), chief sergeant (instead of staff sergeant), and private class I (instead of lance-corporal). ${ }^{17}$ These proved unacceptable and their use was suspended after only two months; after further consideration the title combat general was resumed, while lieutenants became field cornets and second lieutenants became assistant field cornets. ${ }^{18}$ The original British rank titles were restored in $1968^{19}$, and as commandant-general had reverted to plain general (as a rank) in $1967^{20}$, commandant remains the only one of $\mathrm{Mr}$ Erasmus's rank designations still in use.

Military chaplains were given the status of colonels in 1968, with special badges in place of the ordinary rank insignia. Christian chaplains wear a purple triangle bearing the monogram $X P$, while Jewish chaplains wear the shield of David on purple tablets of the law. ${ }^{21}$

The rank of chief commandant, wearing a castle, a star and a spray of laurel leaves, was introduced into the commandos in 1968, but was discontinued two years later. ${ }^{22}$

Non-commissioned officers reverted to wearing British-style chevrons when the current "stepout" uniform was introduced in 1975-76. ${ }^{23}$

A major South African innovation has been the adoption of coloured cloth backings and supplementary insignia to indicate senior positions held by warrant officers first class. This began with the introduction of the post of Sergeant-Major of the Army in 1967, and according to the chart published in the December 1988 Paratus there are now more than a dozen such badges in use in the various arms of the defence force. Those 
exclusive to the army are Regimental SergeantMajor (red backing), Brigade Sergeant-Major, Group Sergeant-Major, Sector Sergeant-Major, SA Army Logistics Command Sergeant-Major, and RSM Army Battle School (green backing), Command Sergeant-Major (black backing), Division Sergeant-Major (green backing with the divisions number above the coat of arms), and Sergeant-Major of the Army (black backing with the army badge above the coat of arms). Army warrant officers can also hold the cmmon service posts of Sergeant-Major of Special Forces (black with the SF badge above), SergeantMajor of the Inspector-General (green with the SADF badge and IG above), and SergeantMajor of the SADF (black with the SADF badge above). ${ }^{24}$

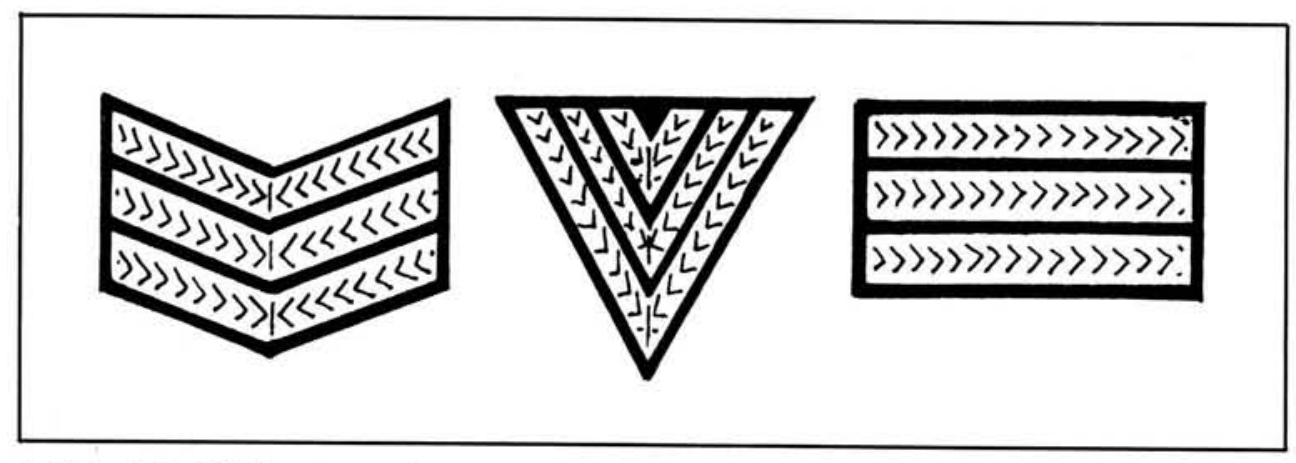

Left to right: British pattern chevrons; German pattern chevrons; SWATF rank stripes.

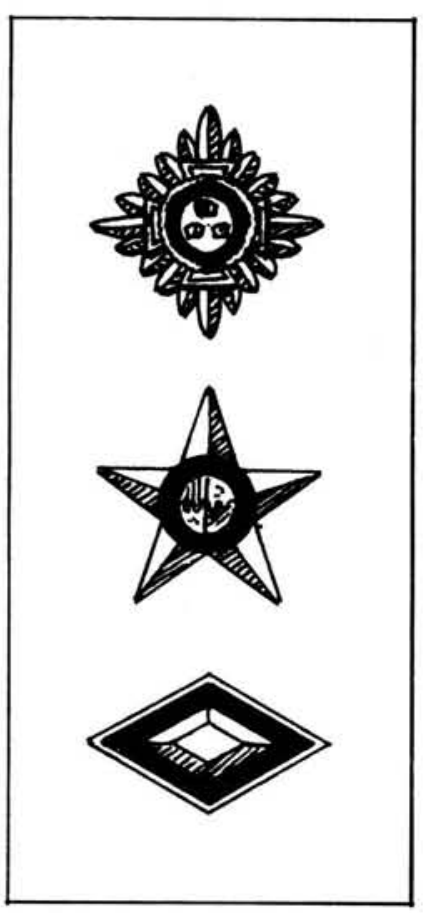

Top to bottom: British rank star; South African rank star; SWATF diamond.

This concludes this survey of South African Army ranks but mention should also be made of the insignia worn by the now defunct South West Africa Territory Force (1980-90). Non-commissioned officers wore horizontal stripes instead of chevrons, while warrant officers wore a triangu-

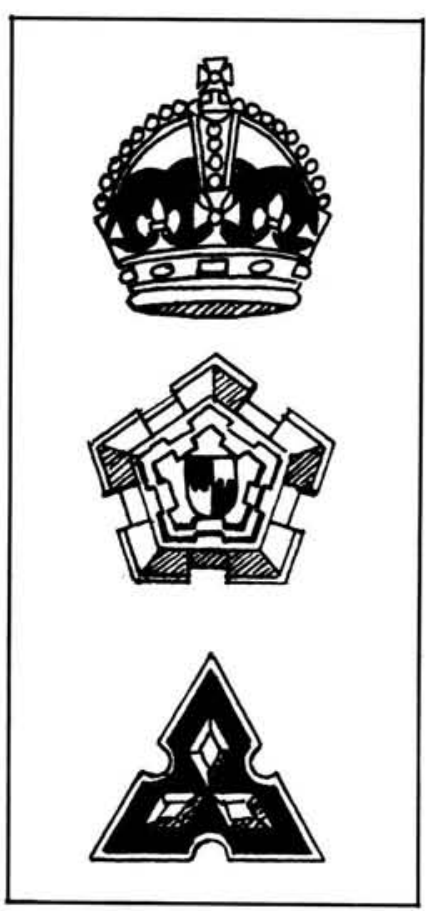

Top to bottom: King's crown; castle; SWATF diamond cluster.

lar diamond cluster with or without surrounding wreath; formation sergeants-major wore black cloth backings, the Sergeant-Major of the SWATF wore black with a single diamond above, and other warrant officers first class wore green backings. Officers' rank stars were replaced by 
diamonds and the castle by the diamond cluster. The brigadier wore a diamond and a crossed sword and baton, while the major-general (the highest rank) wore a diamond cluster and a crossed sword and baton. ${ }^{25}$ These insignia are now obsolete.

* w/0 2 A.V. Radburn, Regimental Historian, Cape Town Rifles (Dukes).

\section{REFERENCES AND SOURCES}

1. Government Notices 1533 (6 Nov 1912) and 1766 (24 Dec 1912).

2. MAY, W.E., CARMAN, W.Y. and TANNER, J.: Badges and Insignia of the British Armed Services (1974) for these and all other details of British ranks.

3. General Orders 153 and 154 (29 Dec 1914)

4. Government Notice 2347 (29 Dec 1920).

5. Government Notice 1567 (29 Nov 1918).

6. Government Notice 1819 (11 Nov 1921).

7. Compliments and Saluting (DHQ publication 1941).

8. Government Notice 171 (26 Jan 1923).
9. General Order 8541 (31 Mar 1937) and Adjutant General's letter AG (1) 189/205 (22 Jul 1937)

10. Government Notices 1770 (1 Nov 1940) and 1369 (25 Aug 1944).

11. Government Notices 501 (4 Apr 1941) and 1766 (12 Dec 1941) and rank chart in The Nongqai, February 1941

12. CURSON, H.H.: More Military and Police Devices (1962).

13. Commando, December 1950, and CURSON. H.H.; Regimental Devices in South Africa (1954)

14. Government Notice 2092 (25 Aug 1950).

15. Government Notice 1737 (21 Sep 1956) and Commando, September 1956.

16. Commando, March 1957.

17. Commando, December 1959 and SADF Order $21 / 60$.

18. ORPEN, N.: The Cape Town Highlanders (1970), and Adjutant General's signal A563 (28 Jun 1960).

19. Commando, July 1968 and Government Notices R 1323-1325 (2 Aug 1968).

20. Government Notice R1252 (18 Aug 1967)

21. Commando, June 1968 and SADF Order $45 / 68$.

22. Commando, July 1968 and September 1970, and Government Notice R266 (28 Feb 1969)

23. Personal recollection

24. Paratus, December 1988

25. Paratus, September 1979

\section{KENNISGEWING/NOTICE}

Nie-amptelike ontvangers van Militaria word daaraan herinner dat hul jaarliks voor die einde van die gestelde keerdatum 30 September van elke jaar ' $n$ hernuwingskennisgewing aan die Redakteur Militaria moet stuur. Versuim om dit te doen sal aanvaar word as 'n aanduiding dat die geadresseerde die blad nie meer wil ontvang nie. Tussentydse kennisgewings van adresverandering onthef nie-amptelike ontvangers nie van die verpligting om hul intekening jaarliks te hernu nie.

Geliewe die nommer wat in die regterkantste boonste hoek van $u$ adresplakkertjie verskyn te kwoteer by hernuwing van u intekening. Dit is baie belangrik.
Non-official recipients of Militaria are reminded that they have to submit a notice of renewal to the Editor Militaria yearly before the set date of 30 September. Failure to do this will be regarded as an indication that the addressee no longer wishes to receive the magazine. Interim notices of change of address do not absolve non-official recipients from the requirement of renewing their subscription on a yearly basis.

Kindly quote the number appearing in the top right hand corner of your address sticker when renewing your subscription. This is most important. 